\title{
National Security Concerns and India's Expanding Naval Presence in the Indian Ocean
}

\author{
Mohammed Khalid \\ Department of Evening Studies, Panjab University, Chandigarh, India \\ Email address: \\ mdkhalidchd@yahoo.com
}

\section{To cite this article:}

Mohammed Khalid. National Security Concerns and India's Expanding Naval Presence in the Indian Ocean. Journal of Political Science and International Relations. Vol. 4, No. 3, 2021, pp. 72-77. doi: 10.11648/j.jpsir.20210403.11

Received: May 4, 2021; Accepted: June 29, 2021; Published: August 18, 2021

\begin{abstract}
National security ensures the existence of the state through economic power, political power, diplomacy and military power. In the contemporary times military might and defense preparedness is just one aspect of national security and it surround a wide range of non-military variables such as economic security, energy security, environmental security etc. In this context each country has to devise means and methods to protect itself from internal and external threats. Military or defense preparedness however remain a foremost manifestation of national security. All the super powers, major or regional powers maintain security forces which protect country's national interest and create deterrents to secure themselves. India is a large country of sub-continental dimensions and a major power of South Asia. Its borders touch Bangladesh, Bhutan, China, Nepal, Myanmar, and Pakistan. It has a long maritime boundary, territorial waters and resource rich continental shelf. Its presence into the Indian Ocean is bolstered by hundreds of islands such as the Andaman and Nicobar Islands and the Lakshadweep Islands. India has a security environment around its borders and in the adjoining ocean which is full of challenges. The Indian Ocean, on which depends its maritime trade, its Exclusive Economic Zone (EEZ) from which it extracts bulk of its oil needs need to be protected. India faces the challenge of rising terrorism, Somalia born sea piracy, security of sea lanes of communications (SLOCS), protection of its valuable and coveted assets at sea and a plethora of other national security concerns. These challenges motivated India to build and develop a strong navy and show its naval presence throughout the length and breadth of the Indian Ocean. Over the years, India has expanded its naval outreach to become a leading naval power of the region. It has also made strategic use of its nave and used it as a diplomatic tool to build relationships with other major powers within and outside the region. After a strong and formidable build up, Indian Navy has emerged to become the fifth largest in the world. It is a potent force known for its professional competence. In this light the paper throws light on the expanding might of Indian Navy to protect Country's national security. The paper is an attempt to understand and analyze the national security threats and contribution of its navy to stamp these threats and help India in its power projection in the Indian Ocean region.
\end{abstract}

Keywords: Polarization, Insurgency, Exclusive Economic Zone, Exploration, Hinterland, Hydrothermal, Bilateral-exercise, Indo-Pacific

\section{Introduction}

National Security is a condition where a nation's important values and beliefs, way of life, institutions of governance, unity, welfare and well-being are permanently and continuously protected. This includes social and political stability, territorial unity, economic strength and solidarity, ecology, socio-cultural coherence and external peace etc. National security environment is imbued with internal as well as external dimensions. Internal threats to national security include organized crime, terrorism, prevalence of grave poverty, serious economic disparities between rich and the poor, communal polarization, economic sabotage, graft and corruption etc. Similarly, external threats include border disputes, illegal migrations, cross border terrorism, cybernetic crime etc. [1]

\section{India's Threat Perceptions}

National security has always been India's primary concern. As the national security is always seen in a context and situation it can be better defined and ensured keeping in view 
time and space. India faces various national security challenges arising from the upheavals in its neighborhood. To begin with, the security situation in Afghanistan remains volatile. Once the U.S forces complete their withdrawal from Afghanistan in September 2021, the Afghan National Security Forces may not prove capable to handle the Taliban. [2] On the other hand Pakistan considers Afghanistan as its much-required "strategic depth" against India and will continue to hob-nob and strengthen its leverage through militant groups like Taliban or the Haqqani network to establish a favorable regime in Kabul. [3] India also faces a continuous threat from Pakistan based terrorist outfits crossing into India focusing on Kashmir and other targets. Quite frequent ceasefire violations by Pakistani security forces targeting border posts and civilian population is another serious threat to India's national security. Chinese troops intermittently intrude across the hazily agreed Line of Actual Control (LAC). The clash in Galwan Valley on the night of $15^{\text {th }}$ June, 2020 taking lives of 20 Indian soldiers and an unspecified number of Chinese soldiers has taken the military stand-off level between the two countries to the next level. China's objections against India to the development of infrastructure in forward posts, observatory positions, electricity poles and upgraded road and air connectivity along the LAC. China's claims of territory inside India, at many places along the border, showing entire Arunachal Pradesh and some areas of Ladakh as its parts, and China's growing influence in the countries of South Asia are India's major security challenges. Activities of some foreign rooted terrorist networks and infiltrations have been posing a serious security threat to India. Many tribal insurgent groups like National Socialist Council of Nagaland and ULFA, crisscrossing the Indo-Myanmar border and operating in north eastern states of India, are another threat to the national security. [4] There are a plethora of other challenges to India's national security, however we here confine ourselves to the external security concerns emanating or pertaining to the Indian Ocean. It is also an attempt to showcase India's naval strategy to deal with such threats.

India is uniquely located with its triangular shaped southern peninsula extending out for about $3,000 \mathrm{~km}$ into the sea. Its shores are washed by the Bay of Bengal towards the east and the Arabian Sea on the west. With a coastline of 7,516 km and having a total of 1,197 island territories in the Bay of Bengal and the Arabian Sea, India has an Exclusive Economic Zone (EEZ) of nearly 23,72,298 sq. $\mathrm{km}$. [5] About 90 percent of India's trade by volume and 77 percent of its trade by value depends on the Ocean. Its EEZ is rich with resources and contributes 68 percent of its oil production (at Bombay High) and 2.82 million ton of its annual fish production. Country's entire oil and gas supplies are imported through the ocean. Therefore, its economy and development are crucially dependent on the waters of the Indian Ocean. To protect its strategic assets in the Indian Ocean is a primary national security concern for the Country.

\section{Face of India's Ocean Centric Threats}

India's strategic security concerns in the Bay of Bengal and Arabian Sea include the need to address and to ensure the safety of chokepoints in the region such as the Straits of Hormuz, the Bab-el-Mandeb, and the Malacca Straits which are of considerable strategic importance. Continuous volatility in the Persian Gulf and Somalia based piracy near Bab - el - Mandeb are issues of concern. [6] Protection of sea lines of communication (SLOCs) and broadband communication connections linked by undersea cables traversing the Indian Ocean facilitating links with other countries of Asia, Europe, and the United States are of paramount concern for India. Threat to coastal areas and vital installations, including ports, sea bed exploration and exploitation units, oil production ridges at Bombay High are also high on Country's security agenda. Drug trafficking (and the laundering of drug money) is the most dangerous illicit trade in the Indian Ocean and a major national security concern. [7]

China is gradually extending its presence in the Indian Ocean Region with speedily spreading its naval presence with array of advanced nuclear submarines, destroyers and frigates and other trained long-range deployments. China has set up a range of military and commercial facilities and established relations with countries along sea-lanes (SLOCS) in the Indian Ocean. Called as String of Pearls, China has expanded its geopolitical influence to increase access to ports and airfields, and intensified its naval presence around India. Such Chinese presence running through some important maritime waterways like the Strait of Mandeb (Bab-elMandeb), Malacca Strait, the Strait of Hormuz and the Lombok Strait (connecting the Java Sea to the Indian Ocean), as well as other strategic ports in Pakistan (Gwadar port), Sri Lanka (Hambantota Port), Bangladesh (Chittagong Port), Myanmar (Great Coco Island), and Maldives are detrimental to India's national security interests. The forays of China's naval patrols along Somalian coast, and China's participation in multi-nation defense patrols in 2010 and after, show China's rising assertiveness to maintain its naval presence on the shipping routes in the Indian Ocean. China's naval presence has a major national security concern for India. [8]

China's enlarging engagements in the lands in and around the Indian Ocean raise worry among the strategists in India that its growing naval presence, and effective use of so-called "debt-trap diplomacy," might eventually give it weighty military advantages in India's surrounding waters. Apart from naval presence, Chinese research vessels have surveyed polymetallic deposits in the Indian Ocean and intensified efforts to explore for and extract minerals from the seabed. It has deployed research vessel "Dayang-1" under China's State Oceanic Administration (SOA) which has discovered four hydrothermal anomaly areas in the Indian Ocean. China has made successful endeavours to dig out hydrothermal sulfide a seabed deposit containing copper, zinc and precious metals such as gold and silver. It was given approval in 2012 to explore a 10,000 sq. $\mathrm{km}$ poly-metallic sulfide ore deposit on 
the seabed of southwest Indian Ocean ridge. [9] China is not a littoral or even hinterland state of the Indian Ocean, still its claim on the Ocean resources that too at India's door steps potentially poses a fierce challenge and a cause of grievous concern.

\section{India's Efforts at Maritime Security}

To protect its national security interests, Indian Navy has played an important role in shouldering responsibility to provide maritime security. India has the largest naval force among all the countries on the littoral of the Indian Ocean. Supported by the state of art technology, it is a balanced and cohesive three-dimensional force, capable of operating on the large surface and under the waters of the oceans. Not only that, the Indian Navy is fifth largest in the world with upgraded air power, an expanding fleet of combatant ships, and conventional as well as nuclear-powered submarines. The navy has modernized over the years to demonstrate its ambition to extend influence and exhibit its power across the Indian Ocean. India has quite skillfully used its navy to strengthen relations with other littoral countries through joint exercises with their navies, visiting their ports and providing them humanitarian assistance, including disaster relief when required. India has rapidly modernized its navy in recent past by inducting new ships and submarines, is building its own air craft career, and replacing its ageing naval assets. It's navy is fast developing blue-water capabilities to meet the existing and prospective challenges by the adversaries within and from outside the Indian Ocean region. [10]

For the protection of its strategic interests in the Indian Ocean, India has developed multi-layered naval forces. To protect its vital strategic assets in the maritime zone. India had set up in August 1978, the Indian Coast Guard (ICG) to keep regular surveillance of Exclusive Economic Zone (EEZ) and to prevent poaching and narcotic smuggling. The Coast Guard conducts rescue operations and protects marine environment. Indian Coast Guard alone operates around 200armed patrol ships of various sizes for country's maritime law enforcement, search and rescue agency and protect India's maritime interests. [11] To secure its maritime borders India has divided its navy in three regional commands. The Western Naval Command headquartered in Mumbai, the Southern Naval Command based in Kochi (Cochin, Kerala), and the Eastern Naval Command in Vishakhapatnam, (Andhra Pradesh). India has also developed important bases in Kolkata and Goa. To use its strategically located Andaman Islands, a resident naval officer's organization was set up in 1963-64 at Port Blair with a naval garrison and some transport and communication facilities. [12] During the 1980s; naval facilities at Port Blair were significantly upgraded and modernized. In 1985, first naval air station was commissioned at Port Blair and in 2001 India set up a strategic command to make its navy more effective in the Bay of Bengal and the Arabian Sea. In fact, "a re-imagining of how India sees the Andaman and Nicobar Islands is central to build its Oceanic influences". [13]
Naval expansion was undertaken after the end of Cold War in the early 1990s with major modernization programme which included the induction of more destroyers, frigates and hydrographic survey ships etc. It was then planned to build warships, submarines, missile-firing nuclear submarine and a 17,000-ton air defense ship capable to carry twelve to fifteen aircrafts. To modernize the navy, India has made indigenous efforts to become self-reliant in producing naval equipment, construct ships and develop its major sub-systems, produce sensors and weapon systems --with the help of Defence Research and Development Organisation (DRDO) and Defence Public Sector Understandings (PSUs) to become self-reliant in its naval needs and capabilities. [14] Its strategic naval assets include aircraft carrier INS Vikramaditya, amphibious transport dock INS Jalashwa, nuclear-powered submarines INS Arihant and INS Chakra and inventory of a whole range of active naval ships. [15]

In June 2019, Indian Navy had 67,252 regular active personnel and 55,000 reserves including 5,000 persons deployed in the naval aviation wing and had more than 2,000 marine commandos. In October 2020, its navy's operational fleet consisted of one aircraft carrier, one amphibious transport dock, eight landing ship tanks, ten destroyers, thirteen frigates, one nuclear-powered attack submarine, one ballistic missile submarine, fifteen conventionally-powered attack submarines, twenty-three corvettes, one mine countermeasure vessel, four fleet tankers and various other back up vessels and patrol boats of various sized and capacity. These assets of the navy are vital for to establish its authority over the seas. Making India a builder's navy, it commissioned indigenously built destroyer, INS Delhi on November 15, 1997, and INS Mysore on June 2, 1999. With the induction of INS Vikramaditya a modified Kiev-class aircraft career in 2013, and recent induction (August 2014) of its largest indigenously-built warship INS Kolkata and commissioning of 3,300-tonne anti-submarine ship INS Kamorta has made Indian Navy as and one of the best equipped navies. [16] The Navy had also commissioned diesel-electric attack submarines INS Kalvari, on 01 May 2016; INS Khanderi on 12 Jan 2017; INS Karanj on 31 Jan 2018; INS Vela on 06 May 2019; and INS Vagir on 12 Nov 2020. These additions have given the Navy an unparallel edge in the Indian Ocean. Indian navy is now operating from Strait of Malacca to the Gulf of Aden, patrolling pirate infested east coast of Africa about 2,900 km. away from the home ports. India's first indigenously-built ballistic missile submarine (SSBN), the Arihant, armed with short range K-15 missiles, has successfully conducted deterrent patrols since 2018 and in early 2020 triumphantly test fired long-range K-4 missiles. Since 2012 its Navy, armed with S-30 anti-shipping cruise missiles, is operating nuclear-powered attack submarine Chakra which was taken on lease from Russia.

To demonstrate its naval might and as part of naval strategy India gives regular exposure to its naval forces by joint exercises. India has conducted joint naval exercises with world's top navies to increase its outreach and strengthen naval inter-operability vis-a-vis the navies of other countries. 
Indian navy conducts annual joint exercise 'Varuna' with the French Navy, which is held at east coast of India with an objective of facilitating mutual learning and practices. Naval exercise 'Indra' is held every two years with Russian navy with an aim to practice cooperation to enforce maritime laws, check piracy, terrorist activities and drug smuggling cartels. It conducts 'Malabar' exercises with the U.S. Navy off the Goa coast and holds joint exercise 'Konkan' with the Royal Navy of United Kingdom. [17]

Indian Navy had also conducted joint naval exercises with China's Navy in 2003. Beyond the Indian Ocean, Indian Navy has greatly shown its presence in South China Sea and has occasionally called at the ports of Vietnam, Philippines and China. In 2007, Indian navy had conducted naval exercises with Japanese and U.S Navy in the south Pacific Ocean. India and Japan signed a strategic agreement in October 2008 to deploy their navies to jointly patrol the AsiaPacific region. Indian navy has also conducted joint naval exercises with the navies of Vietnam, Philippines and New Zealand. In 2007, India and South Korea agreed on conducting naval exercises every year. India held the first Indian Ocean Naval Symposium (IONS) in 2008 with an objective to provide a forum for all the littoral states of the Indian Ocean to cooperate in regional security and check other maritime challenges. For the last twenty years Indian navy vessels and large ships have called at the ports of Israel, Turkey, Egypt, Libya, Greece, Oman, Thailand, Indonesia, Australia, New Zealand, Tonga, South Africa, Kenya, Qatar, Oman, UAE, Bahrain, Kuwait and some other countries between 2005and 2007. [18] Apart from the joint exercises with navies from outside the region; Indian navy has conducted naval exercises with the countries of Indian Ocean littoral. For instance, Singapore-India Maritime Bilateral Exercises (SIMBEX-08) are held on Andaman Sea and Bay of Bengal every year. Indian Navy participated in military exercises with Australia in April 2019, with ASEAN countries, Myanmar, and Singapore in May, Thailand in September, Qatar and Indonesia in November, and with Russia in December 2019. Similarly, Indian Navy participated in Military exercises with Oman in January 2020, Japan in September, Bangladesh and Sri Lanka in October, and with Australia, Japan and United States in November 2020 .

Indian Navy has hosted MILAN exercise since 1995 providing a platform for the meeting of Asia-Pacific navies. This exercise has greatly facilitated to build greater understanding and cooperation among the participating navies. This multi-nation naval exercise off the Andaman coast is annually held in which navies of Singapore, Indonesia, Myanmar, Bangladesh, Thailand, Australia and New Zealand participate. The exercise has gradually built a meaningful and constructive understanding and fruitful cooperation. To begin with, the MILAN exercise was a small congregation of navies of five nations in 1995 and increased to nine in 2006. In 2008, 13 nations were invited to participate and for the first time Australia deployed a ship to participate in the multinational exercise. In 2012, 14 foreign navies participated in the MILAN and in this exercise held in February 2014 navies and maritime forces of 17 countries participated making it the largest ever gathering. [19] In the MILAN-18, held in March 2018, as many as 16 countries participated in this naval exercise. Indian Navy has registered its presence on Antarctica since 1981 when it first flew to Antarctica. Navy succeeded in Mission Dakshin Dhruv in 2006 when a team of ten naval personnel set out for the remotest corner of the world by Ski traversing to the geographic South Pole.

Navy now is not merely to protect the coastal waters but play a larger role in the Indian Ocean. It has demonstrated enough capability to keep peace in country's adjoining waters and protect security-economic interests. Navy effectively blocked a coup in Maldives attempted by some Tamil rebels in 1988 who had hijacked a vessel and took hostage a senior Maldivian minister. In a joint operation of navy and the Indian Coast Guard in October 1999, it rescued a hijacked Japanese cargo ship, 'Alandro Rainbow', from sea pirates. During the Kargil conflict between India and Pakistan in 1999, navy undertook 'Operation Talwar' blocking the naval and trade routes to safeguard India's maritime assets from a possible attack by Pakistani navy and to deter Pakistan from launching a full-scale war. In 2004, Indian navy remarkably participated in relief operations during the disaster perpetrated by tsunami. India pressed in service above 27 ships to help other countries. In 2006, when hostilities between Lebanon and Israel accelerated, Indian naval ships evacuated more than 2,000 Indian, Sri Lankan, and Nepali expatriates from Lebanon. During the 2015 military intervention by Saudi Arabia and its allies into Yemen, Indian Navy deployed the patrol vessel INS Sumitra to the Yemeni port of Aden and in addition, dispatched the destroyer INS Mumbai and frigate INS Tarkash from Mumbai to provide protection and support to Indian ships in the conflict zone. Two ferries belonging to the Lakshadweep administration, MV Kavaratti and MV Corals, with a capacity of 1,500 passengers were dispatched to Aden. On 1 April 2015, INS Sumitra evacuated 349 Indians. and overall 1,670 Indians were evacuated by Indian Navy ships from the war zone.

Indian Navy saved a distressed Saudi Arabian chemical tanker, fired its machine guns at pirates and sent three speedboats filled with pirates fleeing for the lawless Somali coast in 2008. India deployed its ships to the Internationally Recommended Transit Corridor (IRTC) in the Gulf of Aden and near the pirate infested Somali coast to protect trading and cargo ships on the route to Red Sea and Mediterranean and has undertook counter-piracy operations since October 2008. Navy has also regularly escorted Indian flagged ships and merchant vessels of other countries along this transit corridor. Its naval ships have prevented a large number of piracy attempts on merchant vessels in the Arabian Sea. In furtherance of its counter-piracy missions, in 2011, the navy launched Operation Island Watch to deter and check piracy off the Indian island territories of Lakshadweep archipelago. Navy has recently rescued an Indian ship from pirates and shoot them. During the Iraq crises, India made the "pro-active" moves to rescue its citizens and deployed INS Mysore and 'INS Tarkash' to help 
Indians exit Iraq. [20] Navy deployed two ships, as India rolled out a massive evacuation plan to bring back thousands of its nationals stranded abroad due to the coronavirus-triggered lockdown in May 2020. From the countries of Persian Gulf to Malaysia and the UK to the US, the Indian Navy participated in multi-agency operation christened 'Vande Bharat Mission'. In June 2020, under the navy's Operation "Samudra Setu", naval ship Shardul evacuated more than 200 stranded Indian nationals from Iran. [21]

In the wake of ever-increasing forays of Chinese Navy, the Indian Navy has raised its alert level, increased surveillance and enhanced operational deployment in various parts of the Indian Ocean. India has increased cooperation with the countries outside the Indian Ocean Region (IOR), and deepened collaboration through logistics agreements, such arrangements have facilitated to grant Indian Navy access to port facilities at the U.S. base on Diego Garcia, and the French port of Reunion Island. [22] India has engaged itself in an informal Quadrilateral Security Dialogue, or the "Quad," since November 2017 with the United States, Australia and Japan. The "Quad" has been initiated by the partner countries to develop strategic coordination and collaboration to keep Indo-Pacific sea routes free of any encumbrance. To strengthen maritime cooperation, France has suggested to create the "Paris-New Delhi-Canberra" axis in the IndoPacific region, underlining India's emergence as an influential naval power in the Indian Ocean. The rise of Indian naval physical manifestations has given it a central place in Indian Ocean maritime security paradigm which is increasing by the day. Its participation in the Rim of the Pacific Exercise (RIMPAC), --which is world's largest international maritime warfare exercise, held biennially from Honolulu, Hawaii-- exemplifies Indian navy's expanding presence in and around the Indian Ocean.

\section{Conclusion}

In the rapidly changing global strategic environment, future role of the Indian navy calls it to be a balanced maritime defense force and extend outreach of its operational areas into the South China Sea and Indo-Pacific corridor. India's move to expand naval operations, radius of action and establish as an expeditionary force is akin to changing economic dynamics in the Indian Ocean Region. With the recent and ongoing upgradation and inductions, the Indian Navy is on its way to become a truly blue-water navy and a formidable force in the region. To ensure a secure and peaceful environment in the contiguous waters, and further its political, economic, diplomatic and military objectives, Indian Navy has truly changed its profile with the changing geopolitics of the Indian Ocean --from a traditional British time coast guard to one of the world's largest sea force.

Concerned with the national security, India has redefined its strategic objectives in the Indian Ocean. Over the years, India has strengthened and expanded its and has skillfully used maritime diplomacy by signing logistic agreements with strategically-located countries and island states in and around the Indian Ocean. India's national security concerns have driven it to monitor the naval activity of other regional powers deep into the ocean. From calling at the ports of these countries to joint naval exercises. By establishing radio and radar monitoring station on Madagascar, and installing monitoring capabilities in the Nicobar Islands, Indian Navy has intensified its monitoring capabilities in the Indian Ocean. India' faces many national security challenges emanating from the ocean around it, so it is incumbent for it to strengthen and expand its navy and its operations. Indian Ocean region is rich in oil and minerals making it an energy heartland both in the supply and demand. The region is slowly becoming the driver of global economy. Being of strategic importance, a bridge between the lands of Indian and Pacific oceans even up to the Mediterranean in the West, the region needs a robust security structure and diplomacy. India being at the geographic center of Indo-Pacific has picked up the cudgels to ensure that structure. By strengthening its navy, India has not only become a leading naval power to ensure security in the ocean but also its own national security. Indian navy is thus not merely a fighting force but also a diplomatic tool, an influence builder for India. It is a valued aspect of country's national security which will continue to serve and make India a potent force and formidable power of the Indian Ocean in the future.

\section{References}

[1] Definition of "national security" from the Macmillan Dictionary Macmillan Publishers Limited; Romm, Joseph J. (1993): Defining National Security: the non-military aspects, Foreign Affairs, summer 1993. p. 122. ISBN 978-0-87609135-7.

[2] There are currently 2,500 U.S. troops in Afghanistan, along with 6,346 U.S. contractors. U.S. force levels peaked at 100,000 in 2011. Under a withdrawal agreement signed by the Trump Administration and the Taliban in February 2020, there should be no U.S. troops left in Afghanistan by May 1. The New York Times, February 29, 2020.

[3] Patil, Sameer, "India's top security risks in 2014", Gateway House, Indian Council of Global Relations, 16 January 2014; Garner, Godfrey, "Afghanistan: Prospects post U.S. Withdrawal”, American Diplomacy, March 2013.

[4] Datta, Sreeradha, "Security of India's Northeast: External Linkages", Institute of Defence Studies and Analysis, available at, http://www.idsa-india.org/an-nov-00-8.html DSA Routray, Bibhu Prasad, "India-Myanmar Relations: Triumph of Pragmatism", Jindal Journal of International Affairs, Volume 1, Issue 1, October 2011, pp. 299-321.

[5] See, "Survey of the EEZ", Government of India, Ministry of Earth Sciences, National Centre for Antarctic and Ocean Research (NCAOR), available at, http://www.ncaor.gov.in/pages/researchview/7, retrieved on 26.8.2014.

[6] Khalid, Mohammed, "Somalia and its Lawless Coast: India's Growing Security Responsibility in the Indian Ocean", Journal of Indian Ocean Studies, Vol. 18, No. 1, April, 2010, pp. $67-80$. 
[7] Biswas, Aparajita, "Small Arms and Drug Trafficking in the Indian Ocean Region", Working Paper: No. 4, Centre for African Studies, University of Mumbai.

[8] "China builds up strategic sea lanes", The Washington Times Monday, January 17, 2005; Pehrson, Christopher J, "String of Pearls: meeting the challenge of China's rising power across the Asian littoral", Strategic Studies Institute, July 2006; Shrivastava, Sanskar, "Indian String of Pearls "Unstringing" Chinese String of Pearls Theory", World Reporter, June 2013, See, http://www.theworldreporter.com/2013/06/unstringingchinese-string-of-pearls.html.

[9] "China speeds up Indian Ocean exploration for minerals", The Economic Times, Feb 26, 2014.

[10] "INDIAN NAVY - Modernisation", Defence and Security of India, December 1, 2012; Admiral Joshi, D K, "Indian Navy Building Capabilities to Meet All Threats", Defence Now, available at, http://www.defencenow.com/news/1028; "India's Naval Massive Modernization Program”, Defence News, June 03, 2012.

[11] Details available at Indian Coast Guard official website at https://www.indiancoastguard.gov.in/.

[12] For details of India's naval Commands, see, "Naval Commands", Bharat Rakshak, August 10, 2004; Mahapatra, A B, "Commanding the Ocean", The Public Affair Magazine, Feb. 11, 2002.

[13] Malik, Ashok, "Our string of island theory", Hindustan Times, Chandigarh, September 2, 2014, p. 10.

[14] For the defence sector see, "A brief report on defence sector in India", October 2013, available at, http://www.cci.in/pdfs/surveys-reports/Defence-Sector-inIndia.pdf.

[15] For an inventory of Indian Navy's strategic assets see, "List of Active Indian Navy ships", https://en.wikipedia.org/wiki/List_of_active_Indian_Navy_shi ps.
[16] "India gets its first '90\% indigenous' warship", Business Standard, August 27, 2014; also see, "India launches first home-built anti-submarine ship to counter China", South China Morning Post, August 27, 2014.

[17] For exercise with foreign navies, see, http://indiannavy.nic.in/operations/exercise-foreign-navies.

[18] "India ready for naval exercises with GCC countries", The Hindu December 23, 2007; "Naval flotilla to hold exercises with Persian Gulf states", The Hindu, July 31, 2007; "IndoGerman naval exercises to begin today", The Hindu, April 8, 2008; Indian naval ships coming on courtesy tour. Gulf Times. 24 July 2007.

[19] 'India, 16 Others Take Part in 'Milan 2014' Naval Exercise", The New Indian Express, February 09, 2014; Patil, Y Sameer and David Brewster, "Indian Navy: Shaping regional diplomacy", Gateway House, Indian Council of Global Relations, February 21, 2014.

[20] "Warships on standby for Iraq evacuations, Air India alerted", the Times of India, New Delhi, June 29, 2014; "More Indians evacuated from Iraq: Total number rescued now stands at 34; MEA issues fresh travel advisory", Business Standard, New Delhi, June 25, 2014.

[21] "Indian Navy to evacuate Indian citizens from Iran", The Economic Times, June 8, 2020.

[22] A Ankit Panda, "India, US Sign Logistics Exchange Agreement: What You Need to Know," The Diplomat, last modified August 30, 2016, https://thediplomat.com/2016/08/india-us-sign-lo-gisticsexchange-agreement-what-you-need-to-know/: Press Trust of India, "India, France Sign Strategic Pact on Use of Each Other's Military Bases," Times of India, last modified March 10, 2018, https://timesofindia.indiatimes.com/india/indiafrance-sign-strategic-pact-on-use-of-each-others-militarybases/articleshow/63248889.cms. 